\title{
Traditional knowledge of herbal medicines practiced by Ao-Naga tribe in Nagaland, India
}

\author{
Lanusunep ${ }^{1,5}$, Talisosang Amri' ${ }^{2}$, Asangla N. Jamir ${ }^{3}$, \\ S. Imkongtiba Longkumer ${ }^{4}$ and N. S. Jamir \\ ${ }^{1}$ State Medicinal Plants Board (SMPB), Nagaland, Kohima - 797001, Nagaland, India \\ ${ }^{2}$ Department of Agricultural Extension, SASRD, Nagaland University, Medziphema Campus, \\ Medziphema - 797106, Nagaland, India \\ ${ }^{3}$ Department of Botany, Nagaland University, Lumami, P.O. Mokokchung - 798601, Nagaland, India \\ t Department of Zoology, Nagaland University, Lumami, P.O. Mokokchung - 798601, Nagaland, India \\ ${ }^{5}$ Correspondent Author: lanusuneplkr@gmail.com
}

[Received 23.03.2018; Revised 09.06.2018; Accepted 24.06.2018; Published 30.06.2018]

\begin{abstract}
The paper deals with the first hand investigation of 51 species of herbal medicinal plants used by Ao-Naga tribes of Mokokchung district in Nagaland for treatment of various diseases and ailments. The paper includes the plants' scientific name, local name and diseases treated by the plants reported from the district.
\end{abstract}

Key words: Herbal medicine, Ao-Naga, Nagaland

\section{INTRODUCTION}

Mokokchung district is the homeland of the Ao-Nagas in the state of Nagaland, India. The distict lies between $26.12^{\circ}$ and $26.45^{\circ}$ North Latitude and $94.18^{\circ}$ and $94.50^{\circ}$ East Longitude and covers an area of $1,615 \mathrm{sq} \mathrm{km}$. It is bounded by the state of Assam to its north, Wokha district to its west, Tuensang district to its east and Zunheboto district to its south. Agriculturally and industrially the district is most progressive in the state. Major agricultural regions of the district are Changki-Longnak, Tzurang, Milak and Dikhu valley regions (NER 2012).

The major rivers of Mokokchung district are Milak, Dikhu, Tzürang, etc. and the main agricultural products are rice, maize, orange, tomato and passion fruit. Topographically, the area is mainly mountainous except some areas bordering the Assam valley. The major festivals of Ao-Nagas are Moatsü and Tsüngremong. Majority of the population in the district is concentrated in villages situated at hill-tops surrounded by natural forests. Thus, naturally, the Ao-Nagas have close proximity with nature as that helped them to practice traditional medicine since for generations to treat and cure their various ailments (Mills 1921).

The people of Ao-Nagas prefers to dwell mostly in hill-tops and slopes which are preferably surrounded by dense natural forests. The traditional knowledge on medicinal plants is generally confined with the local medicine men (Kobiraz). However, some secrets of these knowledge can be obtained from them through close contacts and interaction (Jamir 1997).

A good number of research works have been contributed on medicinal plants during the last two decades from the North-eastern region of India (Tiwari et al 1979; Bhattacharjee et al 1980; Borthakur 1981a; Gogoi \& Boissya 1984; Borthakur \& Goswami 1995; Jamir \& 
Upadhay 1998; Bora 1999; Devi et al. 2011; Rajkumari et al. 2013; Zorinpuii \& Lalramnghinglova 2017). However, except a few valuable accounts contributed from the state of Nagaland, (Rao \& Jamir 1982a; Jamir \& Rao 1990; Jamir 1997, 2006; Jamir et al. 2008; Sumitra \& Jamir 2009; Lanusunep \& Jamir 2010; Imchen \& Jamir 2011; Jamir et al. 2011, 2016, Rongsensashi et al. 2013), yet exhaustive studies on ethnomedicinal aspects covering a vast area of the district of Mokokchung have hardly been conducted.

\section{METHODOLOGY}

The information, regarding the uses of herbal medicine for the treatment of various diseases and ailments were collected from the local medicine men or folk healers, village elders, etc. during field trips to different places of the state. The plants were identified with the help of literature, flora works and taxonomists from Nagaland University. All the collected specimens were mounted into herbarium sheets by following the standard technique (Rao \& Jain 1977) and deposited in the Department of Botany, Nagaland University, Lumami.

Before the start of the work mandetory PIC was taken from the healers. For this the purpose of the collection and its scientific utilization was explained to them in local language. The information was collected through open and face to face discussion.

Voucher specimens were processed into mounted herbarium sheets following Jain \& Rao (1977). Plants were identified using floras including The Flora of British India (Hooker 1872 - 1897), Flora of Assam (Kanjilal et al. 1934 - 1940), and Materials for the Flora of Arunachal Pradesh (Hajra et al. 1996; Giri et al. 2008; Chowdhery et al. 2009). The identity of the plants were confirmed by matching with the pre-identified specimens at the Herbarium of the Department of Botany, Nagaland University.

For updated nomenclature and for family delimitation www.theplantlist.org was extensively consulted.

\section{RESULT}

In the present paper, botanical names of plants are arranged alphabetically along with Family and local name followed by parts used and uses are presented in Table 1. In the table, recorded plants are enumerated alphabetacally.

Table 1. Medicinal plants used by Ao-Naga tribe living in the Mokokchung district of Nagaland

\begin{tabular}{|l|l|l|l|}
\hline \multicolumn{1}{|c|}{$\begin{array}{c}\text { Botanical name [Family]; } \\
\text { Voucher specimen }\end{array}$} & Local name & Parts used & \multicolumn{1}{c|}{ Diseases treated } \\
\hline $\begin{array}{l}\text { Acacia pennata } \text { (L.) Willd. } \\
\text { [Fabaceae]; LS - 69 }\end{array}$ & Mezümtong & $\begin{array}{l}\text { Bark, leaves, } \\
\text { inflorescence }\end{array}$ & $\begin{array}{l}\text { Paste of the bark is applied as antidote for } \\
\text { snake-bite; paste of leaves and inflorescence } \\
\text { is applied on bodyache and headache. }\end{array}$ \\
\hline $\begin{array}{l}\text { Adenia hondala } \text { (Gaertn.) } \\
\text { W.J.de Wilde [Passifloraceae]; } \\
\text { LS-89 }\end{array}$ & Ayo moli & Whole plant & $\begin{array}{l}\text { Whole plant is crushed and paste is applied } \\
\text { on snake-bite. }\end{array}$ \\
\hline $\begin{array}{l}\text { Amaranthus tricolor } \text { L. } \\
\text { [Amaranthaceae]; } L S-33\end{array}$ & Ruatong & Whole plant & $\begin{array}{l}\text { Plant extract is applied on leucorrhoea and } \\
\text { haemorrhage; leaf paste is applied as } \\
\text { haemostatic }\end{array}$ \\
\hline $\begin{array}{l}\text { Aralia armata } \text { (Wall. ex G.Don) } \\
\text { Seem. [Araliaceae]; LS-91 }\end{array}$ & Mayang-toklo & Stem, leaves & $\begin{array}{l}\text { Bark is pounded into paste and applied on } \\
\text { any kind of skin diseases. Leaf extract is } \\
\text { also drank along with water for cough and } \\
\text { asthma problems. }\end{array}$ \\
\hline $\begin{array}{l}\text { Artemisia nilagirica } \\
\text { (C.B.Clarke) Pamp. } \\
\text { [Asteraceae]; } L S-53\end{array}$ & Entsüksübatong & Leaves & $\begin{array}{l}\text { Leaf extract is applied on allergy, itching, } \\
\text { burns, sores and wounds; decoction is taken } \\
\text { orally for chronic cough, asthma and fever. }\end{array}$ \\
\hline
\end{tabular}




\begin{tabular}{|c|c|c|c|}
\hline $\begin{array}{c}\text { Botanical name [Family]; } \\
\text { Voucher specimen }\end{array}$ & Local name & Parts used & Diseases treated \\
\hline $\begin{array}{l}\text { Asclepias curassavica } \mathrm{L} \text {. } \\
{[\text { Apocynaceae]; } L S-02}\end{array}$ & $\begin{array}{l}\text { Noklangsang } \\
\text { naro }\end{array}$ & $\begin{array}{l}\text { Root, leaves, } \\
\text { latex }\end{array}$ & $\begin{array}{l}\text { Root extract is applied for piles; leaf extract } \\
\text { is used for gonorrhea and for dysentery; } \\
\text { latex of the plant is used for removing warts } \\
\text { and corns }\end{array}$ \\
\hline $\begin{array}{l}\text { Bambusa tulda Roxb. } \\
\text { [Poaceae]; } L S-67\end{array}$ & Longmi & $\begin{array}{l}\text { Rhizome, } \\
\text { leaves }\end{array}$ & $\begin{array}{l}\text { Decoction of rhizome is taken for urinary } \\
\text { disorder; leaves are also given to cows for } \\
\text { release of placenta after parfuration }\end{array}$ \\
\hline $\begin{array}{l}\text { Catharanthus roseus }(\mathrm{L} .) \\
\text { G.Don [Apocynaceae]; } L S-10\end{array}$ & Tsüenlari naro & Leaves & $\begin{array}{l}\text { The decoction of the fresh leaves is taken for } \\
\text { high blood pressure, asthma and diabetes. }\end{array}$ \\
\hline $\begin{array}{l}\text { Citrullus lanatus (Thunb.) } \\
\text { Matsum. \& Nakai } \\
\text { [Cucurbitaceae]; } L S-88\end{array}$ & Abangmatsü & Fruits, seeds & $\begin{array}{l}\text { Fruit is eaten for joint pain, urinary problem, } \\
\text { indigestion and high blood pressure; seeds } \\
\text { powder is taken orally for inflammation of } \\
\text { urinary tract prostrate and hypertension }\end{array}$ \\
\hline $\begin{array}{l}\text { Plectranthus amboinicus } \\
\text { (Lour.) Spreng. [Lamiaceae]; } L S \\
-38\end{array}$ & Kolius naro & Leaves & $\begin{array}{l}\text { Decoction of leaves is taken for urinary } \\
\text { problems, cough, chest pain and vaginal } \\
\text { discharges }\end{array}$ \\
\hline $\begin{array}{l}\text { Crateva nurvala Buch-Ham. } \\
\text { [Capparaceae]; } L S-72\end{array}$ & Enka tong & Bark, leaves & $\begin{array}{l}\text { Paste of the bark is taken orally for } \\
\text { stomachache, as laxative and kidney } \\
\text { problems; fresh leaves is cooked and eaten } \\
\text { as tonic and appetizer }\end{array}$ \\
\hline $\begin{array}{l}\text { Picria fel-terrae } \text { Lour. } \\
\text { [Linderniaceae]; } L S-81\end{array}$ & Longritong & Leaves & $\begin{array}{l}\text { Dried leaves and inflorescence are pounded } \\
\text { into powder and eaten orally along with } \\
\text { common salt for chronic dysentery and } \\
\text { stomachache. }\end{array}$ \\
\hline $\begin{array}{l}\text { Datura stramonium L. } \\
\text { [Solanaceae]; } L S-14\end{array}$ & Metoksuben & $\begin{array}{l}\text { Leaves, } \\
\text { flowers }\end{array}$ & $\begin{array}{l}\text { Extract of leaves and flowers are applied on } \\
\text { boil, sores, ear-ache and body pain. Fruit is } \\
\text { poisonous; sedative, intoxicating and its } \\
\text { extract is applied as hair tonic and for } \\
\text { dandruff }\end{array}$ \\
\hline $\begin{array}{l}\text { Diplazium esculentum (Retz.) } \\
\text { Sw. [Athyriaceae]; } L S-15\end{array}$ & Enchen & Leaves & $\begin{array}{l}\text { Young tender leaves is used as vegetable } \\
\text { and as tonic }\end{array}$ \\
\hline $\begin{array}{l}\text { Distemon indicum Wedd. } \\
\text { [Urticaceae]; } L S-44\end{array}$ & Aokzaklo & Roots & $\begin{array}{l}\text { Bark is pounded into paste and plastered on } \\
\text { dog and snake-bite }\end{array}$ \\
\hline $\begin{array}{l}\text { Equisetum arvense } \mathrm{L} \text {. } \\
\text { [Equisetaceae]; } L S-30\end{array}$ & Ring mezoba & Whole plant & $\begin{array}{l}\text { Paste of the whole plant is used as } \\
\text { haemostatic }\end{array}$ \\
\hline $\begin{array}{l}\text { Ficus racemosa } \mathrm{L} \text { [Moraceae]; } \\
L S-75\end{array}$ & Mentsusu & $\begin{array}{l}\text { Bark, fruit, } \\
\text { latex }\end{array}$ & $\begin{array}{l}\text { Bark is taken orally for diabetes, liver } \\
\text { problems, excessive bleeding during } \\
\text { menstruation, nose bleeding and as } \\
\text { germicide; fruit is eaten for dry cough, } \\
\text { spleen and kidney problem; white latex is } \\
\text { applied on boils, piles and tumours }\end{array}$ \\
\hline $\begin{array}{l}\text { Galium elegans Wall. ex Roxb. } \\
\text { [Rubiaceae]; } L S-101\end{array}$ & Teret-mozü & Whole plant & $\begin{array}{l}\text { Whole plant is crushed into paste and } \\
\text { plastered on bone fractures, sprains and } \\
\text { body swellings; it is also applied on chest } \\
\text { pain and throat pain }\end{array}$ \\
\hline $\begin{array}{l}\text { Gnetum gnemon } \mathrm{L} . \\
\text { [Gnetaceae]; } L S-35\end{array}$ & Milemoa & Leaves, seeds & $\begin{array}{l}\text { The leaves and seeds are used as vegetable } \\
\text { and as diuretic }\end{array}$ \\
\hline $\begin{array}{l}\text { Hedyotis scandens Roxb. } \\
\text { [Rubiaceae] } L S-40\end{array}$ & $\begin{array}{l}\text { Chepra } \\
\text { molitong }\end{array}$ & $\begin{array}{l}\text { Root bark, } \\
\text { leaves, } \\
\text { flower }\end{array}$ & $\begin{array}{l}\text { Root bark is crushed into paste and } \\
\text { decoction is taken orally for dysentery, } \\
\text { cholera, jaundice, germicide and as } \\
\text { fortifacient agent; leaf extract is applied on } \\
\text { boil and warts; flower is pounded with Piper } \\
\text { nigrum and taken for treatment of piles. }\end{array}$ \\
\hline $\begin{array}{l}\text { Hibiscus sabdariffa L. } \\
\text { [Malvaceae]; } L S-109\end{array}$ & Entsürep & Leaves, calyx & $\begin{array}{l}\text { Decoction of leaves and calyx is taken for } \\
\text { indigestion, jaundice, gall bladder stones } \\
\text { and kidney problems }\end{array}$ \\
\hline
\end{tabular}




\begin{tabular}{|c|c|c|c|}
\hline $\begin{array}{l}\text { Botanical name [Family]; } \\
\text { Voucher specimen }\end{array}$ & Local name & Parts used & Diseases treated \\
\hline $\begin{array}{l}\text { Imperata cylindrica (L.) } \\
\text { Raeusch. [Poaceae]; LS }-25\end{array}$ & Aitong & Roots & $\begin{array}{l}\text { Roots are chewed for chronic dysentery, } \\
\text { piles, haemostatic and intestinal parasites } \\
\text { like round-worms, hook-worms and other } \\
\text { amoebic germs }\end{array}$ \\
\hline $\begin{array}{l}\text { Jatropha curcas } \mathrm{L} . \\
\text { [Euphorbiaceae]; } L S-05\end{array}$ & Rujenjang & $\begin{array}{l}\text { Latex, stem } \\
\text { bark, seed oil }\end{array}$ & $\begin{array}{l}\text { Latex is applied on scabies, boils and } \\
\text { rheumatism. Stem bark and leaves is } \\
\text { crushed into paste and taken orally for } \\
\text { dysentery, toothache and lactation. Seeds oil } \\
\text { is used as purgative, anthelmentic and } \\
\text { abortifacient. }\end{array}$ \\
\hline $\begin{array}{l}\text { Lagerstroemia speciosa (L.) } \\
\text { Pers. [Lythraceae]; } L S-23\end{array}$ & $\begin{array}{l}\text { Arongtsüba } \\
\text { sung }\end{array}$ & $\begin{array}{l}\text { Stem bark, } \\
\text { fruit }\end{array}$ & $\begin{array}{l}\text { Stem bark and leaf is pounded into paste and } \\
\text { taken orally for diabetes, diarrhea, fever and } \\
\text { as laxative; paste of the fruit is applied on } \\
\text { mouth ulcers }\end{array}$ \\
\hline $\begin{array}{l}\text { Litsea cubeba (Lour.) Pers. } \\
\text { [Lauraceae]; } L S-55\end{array}$ & Anget & Leaves, fruit & $\begin{array}{l}\text { Leaf paste is applied on allergy, skin } \\
\text { diseases and as haemostatic; fruit is taken } \\
\text { orally for hysteria, dizziness and paralysis }\end{array}$ \\
\hline $\begin{array}{l}\text { Lygodium flexuosum }(\mathrm{L} .) \mathrm{Sw} . \\
\text { [Lygodiaceae]; } L S-27\end{array}$ & Inchen-yangla & Root & $\begin{array}{l}\text { Decoction of the crushed root is applied as } \\
\text { massaging oil in joint pains, rheumatism and } \\
\text { sprains }\end{array}$ \\
\hline $\begin{array}{l}\text { Melastoma malabathricum L. } \\
\text { [Melastomataceae]; } L S-41\end{array}$ & $\begin{array}{l}\text { Imlaklasü- } \\
\text { tepetiba }\end{array}$ & Bark, leaves & $\begin{array}{l}\text { Paste of the bark and leaves is applied on } \\
\text { skin diseases and also taken orally for } \\
\text { dysentery and diarrhea }\end{array}$ \\
\hline $\begin{array}{l}\text { Mesua ferrea } \mathrm{L} \text {. } \\
\text { [Calophyllaceae]; } L S-36\end{array}$ & Mangitong & $\begin{array}{l}\text { Flower, seed } \\
\text { oil }\end{array}$ & $\begin{array}{l}\text { Flower is pounded into paste and taken } \\
\text { orally for chronic dysentery, piles and } \\
\text { leucorrhoea; oil extract from seeds is used } \\
\text { for skin diseases and body pain }\end{array}$ \\
\hline $\begin{array}{l}\text { Mimosa pudica } \mathrm{L} \text {. } \\
{[\text { Fabaceae]; } L S-07}\end{array}$ & Mayak naro & Leaves, root & $\begin{array}{l}\text { Leaf paste is applied on boils, sores, ulcers } \\
\text { and mumps; root and leaf paste is applied on } \\
\text { abdominal pain after child-delivery }\end{array}$ \\
\hline $\begin{array}{l}\text { Mussaenda roxburghii Hook.f. } \\
\text { [Rubiaceae]; } L S-18\end{array}$ & Lenpinaro & $\begin{array}{l}\text { Bark, root, } \\
\text { leaves }\end{array}$ & $\begin{array}{l}\text { Paste of bark and root is taken orally along } \\
\text { with a teaspoon of honey for cough, fever } \\
\text { and as appetizer; leaf paste is applied as } \\
\text { haemostatic }\end{array}$ \\
\hline $\begin{array}{l}\text { Oroxylum indicum (L.) Kurz. } \\
\text { [Bignoniaceae]; } L S-49\end{array}$ & Mesütong & $\begin{array}{l}\text { Stem, root, } \\
\text { leaves }\end{array}$ & $\begin{array}{l}\text { Stem and root is made to paste and taken } \\
\text { orally for asthma and dysentery; leaf extract } \\
\text { is used for epilepsy, rheumatism and liver } \\
\text { problems }\end{array}$ \\
\hline $\begin{array}{l}\text { Leptochilus decurrens Blume } \\
\text { [Polypodiaceae]; } L S-59\end{array}$ & $\begin{array}{l}\text { Enchen } \\
\text { yangliwaba }\end{array}$ & Rhizome & $\begin{array}{l}\text { Rhizome is crushed to powder and taken for } \\
\text { impotency }\end{array}$ \\
\hline $\begin{array}{l}\text { Pteridium aquilinum (L.) Kuhn. } \\
\text { [Dennstaedtiaceae]; } L S-80\end{array}$ & Asang & $\begin{array}{l}\text { Rhizome, } \\
\text { Leaf }\end{array}$ & $\begin{array}{l}\text { Rhizome and leaf is crushed into paste and } \\
\text { its decoction is taken for chronic spleen and } \\
\text { to expel intestinal worms }\end{array}$ \\
\hline $\begin{array}{l}\text { Punica granatum L. } \\
\text { [Lythraceae]; LS - 99] }\end{array}$ & Talimjang & $\begin{array}{l}\text { Leaf, root, } \\
\text { fruit }\end{array}$ & $\begin{array}{l}\text { Tender leaf is taken orally for dysentery, } \\
\text { cholera and stomachache; root bark is } \\
\text { crushed to paste and its decoction is taken as } \\
\text { anthelmintic like tape worms, hook worms; } \\
\text { fruit juice is used as tonic and laxative }\end{array}$ \\
\hline $\begin{array}{l}\text { Rhus chinensis Mill. } \\
\text { [Anacardiaceae]; } L S-96\end{array}$ & Tangma-tong & Seed & $\begin{array}{l}\text { The powdered seeds mixed with common } \\
\text { salt is a common remedy for cholera, } \\
\text { dysentery and diarrhoea; also used as an anti- } \\
\text { allergy. }\end{array}$ \\
\hline $\begin{array}{l}\text { Rubia cordifolia } \mathrm{L} . \\
\text { [Rubiaceae]; } L S-09\end{array}$ & Temerem-juba & Stem, leaf & $\begin{array}{l}\text { Stem and leaf is crushed into paste and its } \\
\text { decoction is used as tonic and vermifuge }\end{array}$ \\
\hline $\begin{array}{l}\text { Saccharum officinarum } \mathrm{L} \text {. } \\
\text { [Poaceae]; } L S-06\end{array}$ & Motsütong & Culm & $\begin{array}{l}\text { Culm is chewed for jaundice and tonic; root } \\
\text { is taken orally for low blood pressure, } \\
\text { bronchitis and anaemia }\end{array}$ \\
\hline
\end{tabular}




\begin{tabular}{|c|c|c|c|}
\hline $\begin{array}{c}\text { Botanical name [Family]; } \\
\text { Voucher specimen }\end{array}$ & Local name & Parts used & Diseases treated \\
\hline $\begin{array}{l}\text { Saccharum officinarum } \mathrm{L} . \\
\text { [Poaceae }] ; L S-06\end{array}$ & Motsütong & Culm & $\begin{array}{l}\text { Culm is chewed for jaundice and tonic; root } \\
\text { is taken orally for low blood pressure, } \\
\text { bronchitis and anaemia }\end{array}$ \\
\hline $\begin{array}{l}\text { Sansevieria roxburghiana } \\
\text { Schult. \& Schult.f. } \\
\text { [Asparagaceae]; LS - 119] }\end{array}$ & Ayu naro & $\begin{array}{l}\text { Rhizome, } \\
\text { leaf }\end{array}$ & $\begin{array}{l}\text { Rhizome extract is taken orally for cough } \\
\text { and throat problems; leaf paste is plastered } \\
\text { in bone fractures and sprains }\end{array}$ \\
\hline $\begin{array}{l}\text { Sida rhombifolia } \mathrm{L} \text {. } \\
\text { [Malvaceae]; } L S-84\end{array}$ & Sangkang & Whole plant & $\begin{array}{l}\text { Plant extract is taken orally for tuberculosis, } \\
\text { urinary problems and rheumatism; infusion } \\
\text { of leaf is used for pulmonary and heart } \\
\text { problems }\end{array}$ \\
\hline $\begin{array}{l}\text { Smilax glabra Roxb. } \\
\text { [Smilacaceae]; LS - 77] }\end{array}$ & $\begin{array}{l}\text { Mangko- } \\
\text { kangling }\end{array}$ & Seed & $\begin{array}{l}\text { Seed is eaten for dysentery, diarrhea and } \\
\text { also used as appetizer }\end{array}$ \\
\hline $\begin{array}{l}\text { Solanum virginianum } \mathrm{L} \text {. } \\
\text { [Solanaceae }] ; \mathrm{LS}-19]\end{array}$ & Entsü longok & Whole plant & $\begin{array}{l}\text { Paste of the whole plant is applied for } \\
\text { cough, asthma and liver disorders; flowers } \\
\text { and fruits are taken as laxative and diuretic }\end{array}$ \\
\hline $\begin{array}{l}\text { Stachytarpheta jamaicensis (L.) } \\
\text { Vahl [Verbenaceae]; } L S-21\end{array}$ & Longri-tong & Leaf & $\begin{array}{l}\text { Decoction of the leaves is used for cholera } \\
\text { and stomach problems. }\end{array}$ \\
\hline $\begin{array}{l}\text { Stevia rebaudiana (Bertoni) } \\
\text { Bertoni [Asteraceae]; } L S-120\end{array}$ & Jenitong & Leaf & $\begin{array}{l}\text { Fresh leaf or dried powder is taken orally for } \\
\text { weight loss, reduce hunger sensation, } \\
\text { diabetes and as tonic }\end{array}$ \\
\hline $\begin{array}{l}\text { Tectaria macrodonta (Fée) C. } \\
\text { Chr. [Dryopteridaceae]; } L S-113\end{array}$ & Enjen & Fronds & $\begin{array}{l}\text { Paste of the fronds is taken orally for } \\
\text { asthma, bronchitis and as anthelmintic }\end{array}$ \\
\hline $\begin{array}{l}\text { Terminalia myriocarpa Van } \\
\text { Heurck \& Mull. Arg. } \\
\text { [Combretaceae]; } L S-94\end{array}$ & Awasüng & Bark & $\begin{array}{l}\text { Bark extract is taken for chest pain, wounds, } \\
\text { injury, diuretic and cardiac stimulant }\end{array}$ \\
\hline $\begin{array}{l}\text { Trema orientalis (L.) Blume } \\
\text { [Cannabaceae]; } L S-110\end{array}$ & Topi-tong & Roots, leaves & $\begin{array}{l}\text { Root bark and fresh leaf is crushed into } \\
\text { paste and taken orally for chronic dysentery, } \\
\text { diarrhea, urinary disorders and epilepsy }\end{array}$ \\
\hline $\begin{array}{l}\text { Viola patrinii Ging. } \\
\text { [Violaceae]; } L S-63\end{array}$ & Chumi naro & Whole plant & $\begin{array}{l}\text { Decoction of the whole plant is taken for } \\
\text { malaria, stomach ulcers and syphilis; } \\
\text { powder of the dried flower is taken for } \\
\text { cough, fever and as purgative }\end{array}$ \\
\hline $\begin{array}{l}\text { Vittaria elongata Sw. } \\
\text { [Pteridaceae]; } L S-46\end{array}$ & Aok enjen & Fronds & $\begin{array}{l}\text { Paste of the fronds is used as massaging for } \\
\text { rheumatism }\end{array}$ \\
\hline $\begin{array}{l}\text { Zanthoxylum oxyphyllum } \\
\text { Edgew. [Rutaceae]; } L S-105\end{array}$ & Monga & Leaf, stem & $\begin{array}{l}\text { Tender leaf is used as vegetable; bark of } \\
\text { stem is used as stimulant, colic and digestive }\end{array}$ \\
\hline $\begin{array}{l}\text { Zea mays L. [Poaceae]; } L S- \\
111\end{array}$ & Ajangtangba & Grains & Grains are nutritive and digestive \\
\hline $\begin{array}{l}\text { Ziziphus jujuba Mill. } \\
\text { [Rhamnaceae]; } L S-117\end{array}$ & Bokore & $\begin{array}{l}\text { Fruit, seed, } \\
\text { bark }\end{array}$ & $\begin{array}{l}\text { Fruits taken as appetizer; seed powder is } \\
\text { used as poultice to boils, diarrhea and for } \\
\text { abdominal pain during pregnancy; pasted } \\
\text { bark is drank along with water for chronic } \\
\text { dysentery }\end{array}$ \\
\hline
\end{tabular}

\section{DISCUSSION}

From the present survey, 51 species of medicinal plants belonging to 51 genera and 40 Families have been recorded. These are represented by just one species of gymnosperm (Gnetum gnemon of Gnetaceae), seven species of pteridophytes and 43 species of Angiosperms and that include 6 species of monocotyledons and 37 species of dicotyledons. Considering the parts of plant used for the treatment of various ailments the leaves are used in highest number of 27 specie, followed by root of 10 spp., bark of 9 spp., whole plant for 7 spp., flowers of 5 spp., 4 stem, 3 latex, 4 rhizome, 5 fruits, 7 seeds, 1 culm, 2 fronds and 1 grain. Out of the 51 plants, $14 \%$ were found to be of a specific singular use while $86 \%$ of the species had multi-purpose value of medicinal properties. Among the dominant families, 
Poaceae and Rubiaceae represented the highest number of species with 4 species each; families of Fabaceae, Asteraceae, Solanaceae, Lythraceae and Malvaceae were represented by 2 species each and 33 species were represented by a single family.

The number of plants species for treatment of various diseases and ailments have the maximum remedy for dysentery (14 spp.), asthma (10 spp.), bodyache, cough, urinary problems ( $8 \mathrm{spp}$. each), haemostatic, skin diseases (6 spp. each), fever, piles ( $5 \mathrm{spp}$. each), female related diseases, diabetes, stomachache (4 spp. each), snake-bite, jaundice, kidney problems ( $3 \mathrm{spp}$. each), high blood pressure, warts, fractures and swellings ( $2 \mathrm{spp}$. each) are some of the significant ailments being treated using the enumerated plants as source of medicine by the Ao-Nagas. Species like Bambusa tulda, Gnetum gnemon, Litsea cubeba, Oroxylum indicum, Rhus chinensis, Stevia rebaudiana and Zanthoxylum oxyphyllum have relatively major market demands within the state for purpose of medicinal values. These marketable plants can be cultivated in the district as the climatic condition is ably suitable for cultivation of such medicinal plants.

\section{CONCLUSION}

It is evident from the present investigation that the Ao-Nagas has deep relationship with the plants of their environment as they still depend on forest resources for healing their ailments and diseases. However, it is unfortunate to note that the younger generations are slowly waning away from this precious knowledge of medicinal plants with the rise of modern medications and technology (Lanusunep 2015).

Moreover, rampant deforestation, 'shifting' or 'jhum' cultivation, coal mining and other socio-economic developments, the rich flora including the wealth of medicinal plants are depleting very fast day by day in the area. Hence, the author(s) stresses upon the urgent documentation, conservation and protection of the medicinal plants from the region. Further phytochemical analysis of these species can provide many interesting and valuable insights on medicinal aspects.

\section{Acknowledgements}

The authors are grateful to Nagaland State Medicinal Plants Board and Forest Department, local medicine men, Gaon Bora, village elders and all those who helped us and shared their folk knowledge and information regarding the usage of medicinal plants during field trips to different localities of Mokokchung district in the state of Nagaland. The authors are also thankful to Shantanu Dey for aiding in identification of the plant specimens.

\section{LITERATURE CITED}

Bhattacharjee, S.; Tiwari,K.C. ;Majumdar, R.\& Misra, A.K 1980, Folklore medicine from district Kamrup (Assam). Bull. Medico. Ethnobot. Res.1: 447 - 460.

Bora, P.J. 1999. A study on ethno-medicinal uses of plants among the Bodo tribe of Sonitpur district, Assam. J. Econ. Tax. Bot. 23(2): 609 - 614.

Borthakur, S.K. 1981. Studies in ethnobotany of Karbis (Mikirs): Plants mastigatories and dyestuffs. In S.K. Jain (Ed). Glimpses of Indian Ethnobotany. Scientific Publisher, Joadhpur. PP. 180 - 190.

Borthakur, S.K. \& Goswami, N. 1995. Herbal remedies from Dimasa of Kamrou district of Assam in North-eastern India. Filoterabia 66(4): 333 - 339. 
Devi, M.R., Singh, P.K., \& Dutta, B.K. 2011. Ethnomedicinal plants of Kabui Naga tribe of Manipur, India. Pleione 5(1): 115 - 128.

Gogoi, P. \& Boissya, C.L. 1984. Information about a few herbal medicines used by the people of Assam (India) against Juandice. Himal. Res. Div. 2: 41 - 44.

Imchen, Kilangnaro \& Jamir, N.S. 2011. Ethnomedicinal plants used by the Phom-Naga tribes in Longleng district of Nagaland, India. Pleione 5(1): $77-82$.

Jamir, N.S. 1997. Ethnobotany of Naga tribe in Nagaland - 1. Medicinal herbs. J. Soc. Ethnobot. 9(1): 101 - 104.

Jamir, N.S. 2006. Indigenous knowledge of medicinal plants in the state of Nagaland. In proceeding on Horticulture for sustainable income and protection 2: $677-683$.

Jamir, N.S. \& Rao R.R. 1990. Fifty new or interesting medicinal plants used by the Zeliang of Nagaland (India). J. Soc. Ethnobot. 2: $11-18$.

Jamir, N.S. \& Upadhayay, D.N. 1998. Studies on some medico-herbs from North-east India. In proceeding on Medicinal plant's herbal heritage Pp. $114-121$.

Jamir, N.S., Jungdan \& Madhabi, S. 2008. Traditional knowledge of medicinal plants used by the Yimchunger - Naga tribes in Nagaland. Pleione 2(2): $223-228$.

Jamir, N.S., Lanusunep \& Manwang Konyak, 2011. Some less known ethnomedicinal plants used by the Angami-Naga tribes in Kohima district, Nagaland. (India). Ethnobotany 23: $116-120$.

Jamir, N.S., Lanusunep \& Sebu, Soyhunlo, 2016. Ethno-medicinal plants used by ChangNaga tribes in Tuensang district, Nagaland (India). Ethnobotany 28: 15 - 18.

Lanusunep, 2015. Traditional practices related to medicinal plants by the Naga tribes in Nagaland. Ph.D Thesis, Department of Botany, Nagaland University.

Lanusunep \& Jamir, N.S. 2010. Folk-medicinal herbs used by the Sumi-Naga tribes of Zunheboto district, Nagaland. Pleione 4(2): 215 - 220.

Mills, J.P. 1921. The Ao Nagas. MacMillan Co. Ltd. London.

NER, 2012. Nagaland Economy Report, 2011-2012 IBEF, India.

Rajkumari, R.; Singh, P.K.; Das, A.K. \& Dutta, B.K. 2013. Ethnobotanical investigation of wild edible and medicinal plants used by Chiru tribe of Manipur, India. Pleione 7(1): $167-174$.

Rao, R.R. \& Jain, S.K. 1977. A Handbook of field and herbarium methods. Today \& Tomorrow's Printers and Publishers, New Delhi.

Rao, R.R. \& Jamir, N.S. 1982. Ethnobotanical studies in Nagaland - 1.52 medicinal plants used by the Nagas. J. Econ. Tax. Bot. 3(1): $11-17$.

Rongsensashi; Renchumi, M.; Sapu Changkija \& Limasenla, 2013. Medicinal plants diversitiey of Fakim Wildlife Sanctuary, Nagaland, India. Pleione 7(1): 110 - 126.

Sumitra, S. \& Jamir, N.S. 2009. Traditionally uses of medicinal plants used by TangkhulNaga tribe in Manipur, India. Pleione 3(2): 157-162.

Tiwari, K.C.; Majumdar, R. \& Bhattacharjee, S. 1979. Folklore medicine from Assam \& Arunachal Pradesh (district Tirap). Intern. J. Crude Drug Res. 17: 61 - 67.

Zorinpuii, Khiangte \& Lalramnghinglova, H. 2017. Inventorisation of indigenous medicinal plants and practices in Mizoram, North East India. Pleione 11(2): 268 - 276. 